\title{
Existing Housing and Feeding Management Practices of Buffaloes in Firozabad District of Uttar Pradesh, India
}

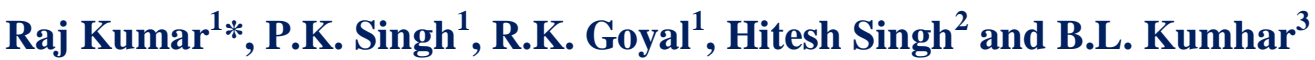 \\ ${ }^{1}$ Department of Animal Husbandry and Dairying, R.B.S. College, Bichpuri, Agra-283105, India \\ ${ }^{2}$ Department of A.H, SVPUAT, Meerut, India \\ ${ }^{3}$ GKMS Project, Agricultural Research Station, Ummedganj, Kota, India \\ *Corresponding author
}

\section{A B S T R A C T}

Keywords

Buffaloes, Housing, feeding, management practices, households.

Article Info

Accepted:

17 April 2017

Available Online:

10 May 2017
Study was carried out in Firozabad district of Uttar Pradesh involving 120 buffalo owners scattered in eight villages of two Tehsil. The farmers were further categorized into three groups viz., small ( $<2$ adult buffaloes), medium ( $>2$ and $<5$ adult bufalloes) and large ( $>$ 5 adult buffaloes) householders. Data pertaining to various aspects of housing and feeding practices were collected through a pre- tested questionnaire. The results indicate that only 60per cent of buffalo owners provide proper housing shelter to their buffaloes, 68.33 per cent respondent's possessed animal house with Kachcha floor with very poor ventilation facilities. Only 54.17 per cent houses have slope for proper drainage of urine and faeces and 64.17 percent respondent's made additional arrangement to protect buffaloes against extreme weather. More than three fourth respondents provide green fodder to buffaloes throughout the year and of them nearly half of them fed it after chaffing. Wheat straw was the sole dry rough age being used by most of the buffalo keepers. 82.50 per cent farmers used homemade concentrate. Only 7.50 per cent respondents offer mineral mixture to their buffaloes. 89.17 per cent buffalo owners fed weighed quantity of concentrate mixture and almost all of them provide it after soaking in water. More than two third respondents fed concentrate mixture before milking. In general results suggest that housing and feeding practices in the study area were not satisfactory and need to be corrected through motivation and providing extension services among the farmers.

\section{Introduction}

The domestication and rearing of buffaloes have an old age practice in India since the era of mediaeval and have been recognized as milch animals along with cows and goats. Currently India has highest buffalo population in the world 96.9 million during 2011 (Kumar et al., 2011). Buffalo is more productive than cattle due to better feed conversion efficiency and more resistant to disease because of above specification buffaloes are now more preferred by the farmers over the cattle.

In Uttar Pradesh the buffalo's population are increasing and outnumber the cattle population simply because of their easy adaptability in harsh environment and producing milk of higher fat content. It is mainstay in production of butter and ghee in 
the country amongst various management practices (feeding, breeding, housing and health care etc.).It is feeding and housing which play a pivotal role in exploiting the genetic potential of animal. Feeding alone contributes about 60-70 percent of total cost of milk production and offers the greatest scope to bring the input-output relationship to an economical level. Besides, providing proper housing to dairy animal is also equally important in order to achieve maximum return from the animals. Better housing arrangements not only provide shelter but also keep the animals in comfortable zone especially during severe environmental conditions i.e. either extreme cold or hot when animals are most vulnerable to get afflicted with stress conditions. Keeping above views in mind the present study was designed to gather information pertaining to housing and feeding aspects of management practices prevailed among various categories of buffalo owners in Firozabad district of western Uttar Pradesh.

\section{Materials and Methods}

A multistage stratified random sampling was adopted to select the respondents. Purportedly Firozabad district famous for glass industry in western Uttar Pradesh during 2011- 2012, out of four two Tehsil viz., Jasarana and Shikohabad of the district were selected. Further, these two Tehsils were divided in to blocks which they constituted. Two blocks one from each tehsil viz., Jasarana and Hath want were taken. Then four villages from each block which in total eight villages were selected. Finally fifteen farmers having varying livestock holdings from each village were taken. Thus in total 120 households were selected randomly for the study. A well structured and pre-tested questionnaire was used to gather information on various aspects of prevailing housing and feeding management practices on buffaloes in the district. The data collected were tabulated and analysed as per standard procedures (Snedecor and Cochran, 1980) (Table 1).

\section{Results and Discussion}

\section{Housing Management Practices}

Results recorded reveal that of the total 66.67 per cent respondents provide housing shelter to their buffaloes while 33.33per cent farmers kept their animals without shelter which is poor indices of housing management. Regarding time spent by the animals in housing shelter, the observations elucidate that only 20.83per cent buffalo owners kept their buffaloes all time in house followed by 49.17per cent farmers who provide housing only at night while 30.00per cent kept their buffaloes in housing only in extreme weather conditions. So far as sharing own house with animals are concerned, 30.83 percent farmers kept buffaloes near their dwelling house, 33.33 per cent inside dwelling house and 35.84per cent had share their house with buffaloes. The results regarding providing housing shelter to buffaloes in present investigation are quite encouraging. Regarding type of shed, roof and floor the results vividly indicate that more than half $(52.50 \%)$ of the farmers possessed Kachcha shed and 47.50 percent had pucca brick cemented shed. 36.67 percent farmers had shed with pucca roof, 33.33 per cent thatched roof and30.00 per cent buffalo owners had shed with asbestos sheet. Similarly majority of the buffalo owners (68.33\%) have housing shelter with Kachcha floor and only nearly one third farmers i.e. 31.67per cent were found to possessed pucca cemented floor for their dairy animals. Further, observations, with respect to type of wall of house, illustrate that of the total 33.33per cent buffalo owners had house with half wall, 30.83per cent with full wall and nearly 35.84per cent with no wall. In sight into data further reveal that only 22.50 per cent respondents provide well 
ventilation in dairy houses, 38.33 per cent kept their buffaloes in semi-ventilated houses and 39.17 per cent provided no ventilation in the house. This trend of observation shows poor knowledge levels of buffalo owners in the surveyed area towards importance of ventilation facilities in the dairy houses. So far as provision of slope in dairy shed is concerned only 24.17 per cent households provide sloppy floor towards back in dairy shed, half of the respondents i.e. 50.83 percent provide levelled floor with no slope, while25.00 per cent possessed house with uneven floor which reflect poor slope provision in the dairy houses. This might be due to lack of awareness of keeping slope in floor to maintain hygienic conditions in the dairy houses. The level of awareness about floor slopes observed during current study is less than what observed in earlier studies. However, notwithstanding the above facts more than half $(54.17 \%)$ respondents provide drainage channel in the shed and about 45.83 percent had no drainage facilities in the buffalo houses. Considerable proportions of respondents $(63.33 \%)$ fed their buffaloes in separate manger, while 36.67 per cent buffalo owners have no manger. This practice may lead to wastage of fodders. So far as architecture of manger is concerned more than half i.e. 56.67 per cent buffalo owners in the surveyed area provide separate manger and 43.33per cent were found to provide manager channel to their buffaloes for feeding. Majority of the buffalo keepers $(60.83 \%)$ used earthen pot as manger, while 39.17 per cent respondents provided cemented manger to their animals. 64.17 per cent farmers made certain extra arrangements against extreme weather conditions particularly during severe cold in winter season to protect their buffaloes. They preferably used gunny/jute bags curtain to cover the houses. Almost all the farmers provided bedding materials to the buffaloes by using paddy straw or other waste dry grasses (Table 2). Similarly results indicated by Mandal et al., 2004; Rathore et al., 2010; Kumar et al., 2011; Singh et al., 2010 and Kumar et al., 2006.

\section{Feeding Management Practices}

\section{Roughages Feeding Practices}

Observations with regard to feeding practices of green and dry rough ages reveal that out of total households surveyed, 80.00 percent of the animal owners provide green fodder to their animals throughout the year and rest i.e. 20.00 per cent provide it occasionally depending upon its availability. Similarly of the whole, 65.83 per cent households used own grown green fodders whereas 34.17 per cent used green fodder either procured from market or scraped grasses from range land, 56.67 per cent buffalo owners provide green fodder after proper chaffing, while considerable number of farmers i.e. 43.33 per cent offers green fodder as such without chaffing. This clearly indicates lack of knowledge among buffalo owners in the study area about importance of chaffing green fodder. Though the current trends recorded in the study are encouraging. Further, results reveal that majority $(66.67 \%)$ of buffalo owners in the district provide green fodder to their animals keeping the bodyweight while remaining i.e. 33.33 per cent farmers do green feeding based on milk yield of the buffaloes. Regarding stall feeding of buffaloes with or without grazing, the observation reflects that major chunk of the buffalo keepers $(85.83 \%)$ in the area under reference sent their buffaloes out for grazing. The results of present finding in this regard are fully corroborated by the findings earlier held by observations pertaining to dry roughages indicate that of the total89.17 per cent of the households fed wheat straw to their buffaloes and the rest used wheat straw and/or paddy straw as sole roughage to their buffaloes. 
Table.1 Socio-economic profiles of respondents

\begin{tabular}{|c|c|c|c|c|}
\hline \multirow[b]{2}{*}{ Attributes } & \multicolumn{4}{|c|}{ Groups } \\
\hline & Small & Medium & Large & Overall \\
\hline Average age (year) & 45.00 & 51.00 & 49.00 & \\
\hline \multicolumn{5}{|c|}{ Value in figure and in bracket was per cent value } \\
\hline Education & & & & \\
\hline a. Up to primary & $29(43.28)$ & $9(25.72)$ & $3(16.67)$ & $41(34.17)$ \\
\hline b. High School & $18(26.86)$ & $13(37.14)$ & $4(22.22)$ & 35 (29.17) \\
\hline c. Intermediate & $12(17.92)$ & $7(20.00)$ & $6(33.33)$ & $25(20.83)$ \\
\hline d. Graduate\& above & $8(11.94)$ & $6(17.14)$ & $5(27.78)$ & $19(15.83)$ \\
\hline Caste & & & & \\
\hline a. Sc/ St & $35(52.24)$ & $11(31.43)$ & $4(22.22)$ & $50(41.67)$ \\
\hline b. OBC & $23(34.33)$ & $14(40.00)$ & $6(33.33)$ & $43(35.83)$ \\
\hline c. General & $9(13.43)$ & $10(28.57)$ & $8(44.57)$ & $27(22.50)$ \\
\hline $\begin{array}{l}\text { Head of the family } \\
\text { a. Male }\end{array}$ & $53(79.10)$ & $30(85.71)$ & 18 & 109 (84.17) \\
\hline b. Female & $14(20.90)$ & $5(14.29)$ & $\begin{array}{c}(100.00) \\
0(0.0)\end{array}$ & $19(15.83)$ \\
\hline Occupation & & & & \\
\hline $\begin{array}{l}\text { a. Agril + Darry } \\
\text { b. Service + Dairy }\end{array}$ & $\begin{array}{l}38(56.72) \\
26(38.80)\end{array}$ & $\begin{array}{l}18(51.43) \\
12(34.28)\end{array}$ & $\begin{array}{l}9(50.00) \\
5(27.78)\end{array}$ & $\begin{array}{l}65(54.17) \\
43(35.83)\end{array}$ \\
\hline c. Dairy & $3(04.48)$ & $5(14.29)$ & $4(22.22)$ & $12(10.00)$ \\
\hline Heard Strength & & & & \\
\hline a. Total Buffalo & 1.75 & 3.6 & 5.5 & \\
\hline b. Milch & 1.15 & 2.5 & 4.4 & \\
\hline c. Dry & 0.6 & 0.9 & 1.1 & \\
\hline d. Heifers & 0.4 & 0.3 & 0.8 & \\
\hline e. Calves & 0.7 & 1.0 & 2.0 & \\
\hline f. Male & 0.3 & 0.6 & 0.9 & \\
\hline g. Female & 0.5 & 0.9 & 1.1 & \\
\hline h. Bull & 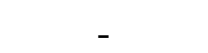 & 0.6 & 1.0 & \\
\hline
\end{tabular}


Table.2 Housing management practices

\begin{tabular}{|c|c|c|c|c|}
\hline \multirow[t]{2}{*}{ Practices } & \multicolumn{3}{|c|}{ Group (\% Households) } & \multirow[b]{2}{*}{ Overall (120) } \\
\hline & Small(67) & Medium (35) & Large (18) & \\
\hline $\begin{array}{l}\text { Providing Housing shelter } \\
\text { Yes } \\
\text { No }\end{array}$ & $\begin{array}{l}40(59.70) \\
27(40.30)\end{array}$ & $\begin{array}{c}27(77.17) \\
8(22.86)\end{array}$ & $\begin{array}{c}13(72.22) \\
5(27.78)\end{array}$ & $\begin{array}{l}80(66.67) \\
40(33.33)\end{array}$ \\
\hline $\begin{array}{l}\text { Providing Housing } \\
\text { (i) All time } \\
\text { (ii) Only at night } \\
\text { (iii) Only in extreme weather }\end{array}$ & $\begin{array}{l}15(22.39) \\
29(43.28) \\
23(34.33)\end{array}$ & $\begin{array}{l}6(17.14) \\
19(54.29) \\
10(28.57)\end{array}$ & $\begin{array}{l}4(22.22) \\
11(61.11) \\
3(16.67)\end{array}$ & $\begin{array}{l}25(20.83) \\
59(49.17) \\
36(30.00)\end{array}$ \\
\hline $\begin{array}{l}\text { Housing Animal } \\
\text { (a) Near dwelling house } \\
\text { (b) Inside dwelling house } \\
\text { (c) Separate from dwelling house }\end{array}$ & $\begin{array}{l}28(41.79) \\
24(35.82) \\
15(45.72)\end{array}$ & $\begin{array}{l}9(25.71) \\
10(28.57) \\
16(45.72)\end{array}$ & $\begin{array}{c}- \\
6(33.33) \\
12(66.67)\end{array}$ & $\begin{array}{l}9(25.71) \\
40(33.33) \\
43(35.84)\end{array}$ \\
\hline $\begin{array}{l}\text { Type of shed } \\
\text { (i) Kachcha } \\
\text { (ii) Pucca } 15 \text { (22.39) }\end{array}$ & $\begin{array}{l}52(77.61) \\
15(22.39)\end{array}$ & $\begin{array}{c}9(25.71) \\
26(24.26)\end{array}$ & $\begin{array}{c}2(11.11) \\
16(88.89)\end{array}$ & $\begin{array}{l}63(52.50) \\
57(47.50)\end{array}$ \\
\hline $\begin{array}{l}\text { Type of roof } \\
\text { (a) Pucca } \\
\text { (b) Thatched } \\
\text { (c) Asbestos }\end{array}$ & $\begin{array}{l}11(16.42) \\
27(40.30) \\
29(43.28) \\
\end{array}$ & $\begin{array}{c}18(51.43) \\
10(28.57) \\
7(20.00) \\
\end{array}$ & $\begin{array}{c}15(83.33) \\
3(16.67) \\
- \\
\end{array}$ & $\begin{array}{l}44(36.67) \\
40(33.33) \\
36(30.00) \\
\end{array}$ \\
\hline $\begin{array}{l}\text { Type of floor } \\
\text { (a) Kachcha } \\
\text { (b) Pucca }\end{array}$ & $\begin{array}{c}61(91.04) \\
6(8.96)\end{array}$ & $\begin{array}{l}21(60.00) \\
14(40.00)\end{array}$ & $\begin{array}{c}- \\
18(100.00)\end{array}$ & $\begin{array}{l}82(68.33) \\
38(31.67)\end{array}$ \\
\hline $\begin{array}{l}\text { Type of wall } \\
\text { (a) Half wall } \\
\text { (b) Full wall } \\
\text { (c) No wall }\end{array}$ & $\begin{array}{c}24(35.82) \\
- \\
43(64.18)\end{array}$ & $\begin{array}{l}16(45.71) \\
19(54.29) \\
-\end{array}$ & $\begin{array}{c}- \\
18(100.00) \\
-\end{array}$ & $\begin{array}{l}40(33.33) \\
37(30.83) \\
43(35.84)\end{array}$ \\
\hline $\begin{array}{l}\text { Ventilation of shed } \\
\text { (a) Well ventilation } \\
\text { (b) Semi Ventilated } \\
\text { (c) No ventilated }\end{array}$ & $\begin{array}{c}- \\
27(40.30) \\
40(59.70) \\
\end{array}$ & $\begin{array}{l}11(31.43) \\
17(48.57) \\
7(20.00) \\
\end{array}$ & $\begin{array}{c}16(88.89) \\
2(11.11) \\
\quad- \\
\end{array}$ & $\begin{array}{l}27(22.50) \\
46(38.33) \\
47(39.17) \\
\end{array}$ \\
\hline $\begin{array}{l}\text { Land of floor } \\
\text { (a) Sloppy } \\
\text { (b) Leveled } \\
\text { (c) Uneven }\end{array}$ & $\begin{array}{c}- \\
44(65.67) \\
23(34.33) \\
\end{array}$ & $\begin{array}{c}15(42.86) \\
13(37.14) \\
7(20.00) \\
\end{array}$ & $\begin{array}{c}14(77.78) \\
4(22.28) \\
\quad- \\
\end{array}$ & $\begin{array}{l}29(24.17) \\
61(50.83) \\
30(25.00) \\
\end{array}$ \\
\hline $\begin{array}{l}\text { Drainage channel in Shed } \\
\text { (a) Yes } \\
\text { (b) No }\end{array}$ & $\begin{array}{l}18(26.87) \\
49(73.13)\end{array}$ & $\begin{array}{c}29(82.86) \\
6(17.14)\end{array}$ & $\begin{array}{c}18(100.0) \\
-\end{array}$ & $\begin{array}{l}65(54.17) \\
55(45.83)\end{array}$ \\
\hline $\begin{array}{l}\text { Provide Separate Manger } \\
\text { Yes } \\
\text { No }\end{array}$ & $\begin{array}{l}27(40.30) \\
40(59.70)\end{array}$ & $\begin{array}{c}31(88.57) \\
4(11.43)\end{array}$ & $\begin{array}{c}18(100.00) \\
-\end{array}$ & $\begin{array}{l}76(63.33) \\
44(36.67)\end{array}$ \\
\hline $\begin{array}{l}\text { Architecture of manger } \\
\text { (a) Separate Manger } \\
\text { (b) Manger channel }\end{array}$ & $\begin{array}{l}22(32.84) \\
45(67.16)\end{array}$ & $\begin{array}{c}29(82.86) \\
6(17.14)\end{array}$ & $\begin{aligned} 17 & (94.44) \\
1 & (5.56)\end{aligned}$ & $\begin{array}{l}68(56.67) \\
52(43.33)\end{array}$ \\
\hline $\begin{array}{l}\text { Types of manger } \\
\text { (a) Earthen pot } \\
\text { (b) Cemented }\end{array}$ & $\begin{aligned} 62 & (92.54) \\
5 & (7.46)\end{aligned}$ & $\begin{array}{l}11(31.43) \\
24(68.57)\end{array}$ & $18(100.00)$ & $\begin{array}{l}73(60.83) \\
47(39.17)\end{array}$ \\
\hline $\begin{array}{l}\text { Arrangement made against extreme weathers } \\
\text { Yes } \\
\text { No }\end{array}$ & $\begin{array}{l}42(62.69) \\
25(37.31)\end{array}$ & $\begin{array}{l}23(65.71) \\
12(34.26)\end{array}$ & $\begin{array}{c}12(66.67) \\
6(33.33)\end{array}$ & $\begin{array}{l}77(64.17) \\
43(35.83)\end{array}$ \\
\hline $\begin{array}{l}\text { Providing bedding materials during winter } \\
\text { Yes } \\
\text { No }\end{array}$ & $\begin{array}{c}67(100.00) \\
-\end{array}$ & $\begin{array}{c}35(100.00) \\
-\end{array}$ & $\begin{array}{c}18(100.00) \\
-\end{array}$ & $120(100.00)$ \\
\hline
\end{tabular}


Table.3 Practices of feeding green and dry roughages to the animals

\begin{tabular}{|c|c|c|c|c|}
\hline \multirow[t]{2}{*}{ Practices } & \multicolumn{3}{|c|}{ Group (\% of Households) } & \multirow[b]{2}{*}{ Overall } \\
\hline & Small & Medium & Large & \\
\hline $\begin{array}{l}\text { Providing green fodder } \\
\text { Yes } \\
\text { No }\end{array}$ & $\begin{array}{l}51(76.11) \\
16(23.89)\end{array}$ & $\begin{array}{c}27(77.14) \\
8(22.86)\end{array}$ & $\begin{array}{c}18(100.00) \\
-\end{array}$ & $\begin{array}{r}96(80.00) \\
24(20.00)\end{array}$ \\
\hline $\begin{array}{l}\text { Green Fodder } \\
\text { Grown } \\
\text { Not grown }\end{array}$ & $\begin{array}{l}31(46.27) \\
36(53.73)\end{array}$ & $\begin{array}{c}30(85.74) \\
5(14.26)\end{array}$ & $\begin{array}{c}18(100.00) \\
-\end{array}$ & $\begin{array}{l}79(65.83) \\
41(34.17)\end{array}$ \\
\hline $\begin{array}{l}\text { Chaffing Fodder } \\
\text { Done } \\
\text { Note done }\end{array}$ & $\begin{array}{l}27(40.30) \\
40(59.70) \\
\end{array}$ & $\begin{array}{c}26(74.29) \\
9(25.71)\end{array}$ & $\begin{array}{c}15(83.33) \\
3(16.67)\end{array}$ & $\begin{array}{l}68(56.67) \\
52(53.33)\end{array}$ \\
\hline $\begin{array}{l}\text { Criteria for feeding green fodder } \\
\text { Milk yield } \\
\text { Body weight }\end{array}$ & $\begin{array}{l}23(34.33) \\
44(65.67)\end{array}$ & $\begin{array}{l}12(34.29) \\
23(65.71)\end{array}$ & $\begin{array}{c}5(27.78) \\
13(72.22)\end{array}$ & $\begin{array}{l}40(33.33) \\
80(66.67)\end{array}$ \\
\hline $\begin{array}{l}\text { Providing stall feeding } \\
\text { With grazing } \\
\text { Without grazing }\end{array}$ & $\begin{array}{c}67(100.00) \\
-\end{array}$ & $\begin{array}{l}24(68.57) \\
11(31.43)\end{array}$ & $\begin{array}{c}12(66.67) \\
6(33.33)\end{array}$ & $\begin{array}{c}103(85.83) \\
17(14.67)\end{array}$ \\
\hline $\begin{array}{l}\text { Types of dry fodder fed to animals } \\
\text { Wheat straw } \\
\text { Paddy Straw } \\
\text { Wheat + Paddy straw }\end{array}$ & $\begin{array}{c}59(88.06) \\
- \\
8(11.94) \\
\end{array}$ & $\begin{array}{c}32(91.43) \\
- \\
3(8.57) \\
\end{array}$ & $\begin{array}{c}16(88.89) \\
- \\
2(11.11) \\
\end{array}$ & $\begin{array}{c}107(89.17) \\
- \\
13(10.83) \\
\end{array}$ \\
\hline $\begin{array}{l}\text { Doing Roughage Feeding } \\
\text { Once } \\
\text { Twice } \\
\text { Thrice }\end{array}$ & $\begin{array}{c}- \\
60(89.55) \\
7(10.45)\end{array}$ & $\begin{array}{c}- \\
32(91.43) \\
3(8.57)\end{array}$ & $\begin{array}{c}- \\
15(83.33) \\
3(16.67)\end{array}$ & $\begin{array}{c}- \\
107(89.17) \\
13(10.83)\end{array}$ \\
\hline $\begin{array}{l}\text { Knowledge about Urea feeding } \\
\text { Yes } \\
\text { No }\end{array}$ & $\begin{array}{c}9(13.43) \\
58(86.57)\end{array}$ & $\begin{array}{c}7(20.00) \\
28(80.00)\end{array}$ & $\begin{array}{c}4(22.22) \\
14(77.78)\end{array}$ & $\begin{array}{c}20(16.67) \\
100(83.33)\end{array}$ \\
\hline $\begin{array}{l}\text { Feeding Urea treated } \\
\text { Yes } \\
\text { No }\end{array}$ & $\begin{array}{c}- \\
67(100.00)\end{array}$ & $\begin{array}{c}- \\
35(100.00)\end{array}$ & $\begin{array}{c}- \\
18(100.00)\end{array}$ & $\begin{array}{c}- \\
120(100.00)\end{array}$ \\
\hline
\end{tabular}

Table.4 Practices of feeding concentrate to the animals

\begin{tabular}{|l|c|c|c|c|}
\hline \multirow{2}{*}{ Practices } & \multicolumn{4}{|c|}{ Group (\% of Households) } \\
\cline { 2 - 5 } & Small & Medium & Large & Overall \\
\hline Procurement of concentrates & & & & \\
Home made & $52(77.61)$ & $31(88.57)$ & $16(88.89)$ & $99(82.50)$ \\
Purchase & $15(22.39)$ & $4(11.43)$ & $2(11.11)$ & $21(17.50)$ \\
\hline Feeding common salt & & & & \\
Yes & $39(58.21)$ & $28(80.00)$ & $15(83.33)$ & $82(68.33)$ \\
No & $28(41.79)$ & $7(20.00)$ & $3(16.67)$ & $38(31.67)$ \\
\hline Feeding mineral mixture & & & & \\
Yes & $5(07.46)$ & $3(8.57)$ & $1(5.56)$ & $9(7.50)$ \\
No & $62(92.54)$ & $32(91.43)$ & $17(94.44)$ & $111(92.50)$ \\
\hline Feeding weighed quantity ofconcentrates & & & & \\
Yes & & & & \\
No & $58(86.57)$ & $33(94.29)$ & $16(88.89)$ & $107(89.17)$ \\
& $9(13.43)$ & $2(5.71)$ & $2(11.11)$ & $13(10.83)$ \\
\hline Soaking concentrates mixture & & & & \\
Yes & $63(94.03)$ & $34(97.14)$ & $18(100.00)$ & $115(95.83)$ \\
No & $4(5.97)$ & $1(2.86)$ & - & $5(4.17)$ \\
\hline Doing concentrates feeding everyday & & & & \\
Before milking & $53(79.10)$ & $27(77.14)$ & $14(77.78)$ & $94(78.33)$ \\
At milking & $10(14.93)$ & $6(17.14)$ & $2(11.11)$ & $18(15.00)$ \\
After milking & $4(5.97)$ & $2(5.72)$ & $2(11.11)$ & $8(6.67)$ \\
\hline Mode of concentrates feeding & $60(89.55)$ & $29(82.86)$ & $15(83.33)$ & $104(86.67)$ \\
With roughages & $7(10.45)$ & $6(17.14)$ & $3(16.67)$ & $16(13.33)$ \\
\hline Without roughages & & & & \\
\hline Supply drinking water daily & $12(17.91)$ & $3(8.57)$ & $3(16.67)$ & $18(15.00)$ \\
Twice & $55(82.09)$ & $32(91.43)$ & $43(83.33)$ & $102(85.00)$ \\
\hline Thrice & & & \\
\hline
\end{tabular}


No farmers was found to use paddy straw as a sole source of roughage because of nonavailability of it in the area, so far as frequency of roughages feeding is concerned about 89.17percent of the households fed their buffaloes twice a day while remaining $(10.83 \%)$ provided roughages thrice a day. Urea can be used to enrich the nutritive value of poor quality roughages but none of the farmers practiced feeding of urea treated straw to their animals. Moreover, only 16.67 percent of the households knew that urea can be fed as supplement to buffalo (Table 3). This phenomenon might be attributed to lack of proper training and knowledge of scientific feeding among the owners and the same need to persuade through extension programme. Similarly results indicated by Kumar et al., 2011; Deoras et al., Singh et al., 2010; Garg et al., 2005; Dhiman et al., 1990 and Kumar et al., 2006.

\section{Concentrate Feeding Practices}

Results pertaining to practices of concentrate feeding reveal that majority of the households $(82.50 \%)$ provide homemade concentrate mixture primarily consist of bran and chuni as major ingredients. However, some segment of livestock owners $(17.50 \%)$ witnessed to have purchased concentrate mixture from the market to fed their buffaloes. Interestingly more than two third of the households appeared to reflect that they knew about the importance of feeding common salts to dairy animals. Of the total, 68.33 percent households provide common salts in concentrate mixture to buffaloes. At the same time only 7.50 percent farmers had witnessed to offer mineral mixtures to their buffaloes (Table 4), this need to be corrected by providing scientific knowledge to them. These results are in conformity with the views earlier held by Singh et al., 2010; Garg et al., 2005; Dhiman et al., 1990 and Kumar et al., 2006 of the total, 89.17 percent households in the study area fed weighed quantity of concentrate mixture and remaining 10.83 percent fed concentrate mixture to buffaloes on arbitrary basis using measuring pot. Before feeding, concentrate mixture was soaked in water for few hours by 95.83 percent households. Major proportion of the farmers $(78.33 \%)$ fed concentrate to buffaloes daily before milking, 15.00 per cent a milking and only 6.67 percent offered it after milking. So far as mode of feeding is concerned, 86.67 percent farmers supplied concentrate along with roughages while 13.33 percent provide concentrate separately to their buffaloes. Majority of the farmers $(85.00 \%)$ offer drinking water thrice a day to their buffaloes. Similar results were also recorded by.

In conclusion, results of current investigation clearly suggest that about one third buffalo owners did not provide proper housing shelter and only few were able to have separate house for their buffaloes. Ventilation and drainage facilities in housing shed were not found proper in the area. Farmers of the area studied appeared to witness of having lack of knowledge about benefits of chaffing fodders, criteria of feeding, enrichment of fodder nutritive value, importance of feeding common salts and mineral mixture to buffaloes. Based on above outstanding facts it could be concluded that housing and feeding management practices prevailed among buffalo keepers in the district were not in tune of standard recommendations and there is much scope to improve them among buffalo owners through motivation and exposer to extension services.

\section{References}

Deoras, R., Nema, R.K., Tiwari, S.P. and Singh, M. 2004. Feeding and housing management practices of dairy animals in Rajnandgaon of Chhattisgarh plain. Indian J. Anim. Sci., 74: 300-306.

Dhiman, P.C., Singh, N. and Yadav, B.L. 
(1990a).A study on cattle and buffalo feeding and breeding practices in adopted and non-adopted villages of Hisar district. Indian J. Anim. Prod. Mgmt., 6: 90-94.

Garg, M.K., Jain, L.S. and Chaudhary, J.L. 2005. Studies onhousing, feeding and milking management practices of dairy cattle in Baran district of Rajasthan. Indian J. Dairy Sci., 58(2): 123-128.

Kumar, Sunil and Mishra, B.K. 2011. Existing feeding andhousing management practices followed by dairy producers in Tehri Garhwal district of Uttarakhand. Indian J. Anim. Prod. Mgmt., 27(3-4): 159-162.

Kumar, U., Mehla, R.K., Chandra, R. and Roy, B. 2006. Studieson managemental practices followed by the traditional owners of Sahiwal cows in Punjab. Indian J. Dairy Sci., 59(2): 100-
105.

Mandal, A.B. Yadav, P.S. and Kapoor, Vanita, 2004. Mineralstatus of buffaloes under farm feeding condition of Faridabad district of Haryana. Indian J. Anim. Nutr., 21(2): 104-110.

Rathore, R.S., Singh, Rajbir and Tiwari, Abha. 2010. Studies on various existing managemental practices followed by the cross bred cattle owners. Indian J. Anim. Prod. Mgmt., 26(1-2): 85-88.

Singh, P.K., Yadav, K.C., Singh, V.P. and Shahi, S.K. 2010. Feeding management practices vis-a-vis nutritional status of buffaloes under field conditions in Agra district of western Uttar Pradesh. Indian J. Dairy Sci., 63(2): 118-121.

Snedecor, G.W. and Cochran, W.G. 1980. Statistical methods. $7^{\text {th }}$ Edn. Iowa State University, Press, Ames, Iowa.

\section{How to cite this article:}

Raj Kumar, P.K. Singh, R.K. Goyal, Hitesh Singh and Kumhar, B.L. 2017. Existing Housing and Feeding Management Practices of Buffaloes in Firozabad District of Uttar Pradesh, India. Int.J.Curr.Microbiol.App.Sci. 6(5): 1831-1838. doi: https://doi.org/10.20546/ijcmas.2017.605.200 